\title{
PENGARUH KEPUTUSAN INVESTASI, KEPUTUSAN PENDANAAN DAN KEBIJAKAN DIVIDEN TERHADAP NILAI PERUSAHAAN PADA PERUSAHAAN LQ 45 DI BURSA EFEK INDONESIA TAHUN 2011-2015
}

\author{
Muhammad Rifki Maulana ${ }^{1}$, Hermanto $^{2}$, I Nyoman. Nugraha A.P. ${ }^{3}$ \\ ${ }^{1}$ Fakultas Ekonomi dan Bisnis Universitas Mataram, rifkimaulana@unram.ac.id \\ ${ }^{2}$ Fakultas Ekonomi dan Bisnis Universitas Mataram, rifkimaulana@unram.ac.id \\ ${ }^{3}$ Fakultas Ekonomi dan Bisnis Universitas Mataram, rifkimaulana@unram.ac.id
}

\begin{abstract}
ABSTRAK
Penelitian ini menguji tentang "Pengaruh Keputusan Investasi, Keputusan Pendanaan dan Kebijakan Dividen terhadap Nilai Perusahaan". Populasi dalam penelitian ini adalah perusahaan yang masuk dalam indeks LQ 45 selama 2011-2015. Metode sampling yang digunakan adalah purposive sampling dengan sampel penelitan berjumlah 14 perusahaan.

Teknik analisis data yang digunakan adalah uji normalitas, uji multikolonieritas, uji autokorelasi, dan uji heteroskedastisitas. Test hipotesis menggunakan analisis regresi berganda. Hasil analisis menunjukkan bahwa variabel Keputusan Investasi, Keputusan Pendanaan dan Kebijakan Dividen memiliki pengaruh yang signifikan terhadap Nilai Perusahaan. Hal ini dapat diketahui melalui uji $\mathrm{F}$ dengan nilai signifikan yang lebih kecil dari $0,05(0,002<0,05)$ yang berarti diterimanya model ini (goodness of fit). Uji t menunjukkan bahwa variabel Keputusan Investasi (TAG) berpengaruh positif dan signifikan Nilai Perusahaan. Sedangkan Keputusan Pendanaan dan Kebijakan Dividen tidak berpengaruh terhadap Nilai Perusahaan. Nilai Ajusted R-Square menunjukkan variabel independepen mampu menjelaskan variabel dependen sebesar $16,3 \%$ sedangkan sisanya sebesar $84,7 \%$ dipengaruhi oleh variabel lain yang tidak dijelaskan dalam model penelitian ini.

Kata kunci: Keputusan Investasi, Keputusan Pendanaan, Kebijakan Dividen, dan Nilai Perusahaan.
\end{abstract}

\section{ABSTRACK}

This research tests the effect of investment decisions, financing decisions, and dividend policy toward the firm value. The population of this research are the companies on $L Q 45$ index during 20112015. Puposive sampling method used with number of samples are 14 (fourteen) companies.

Data analysis technique uses classic assumption test: multicolinierity test, autocorrelation test, heteroscedasticity test, and normality test. Hypothesis test uses multiple regression analysis. The research result shows that the variable of investment decision, financing decision, and dividend policy has significant influence toward the firm value. It could be known throught the f-test with significant value smaller than 0,05 $(0,02<0,05)$ that means the models accepted (goodness of fit). The $t$-test shows that the variable of investment decision (TAG) has positif and significant influence toward the firm value. While the financing decision and dividend policy has not influence toward the firm value. Ajusted R-square value shows that the independent variable could explained the dependent variable of 16,3\% while the balance of $84,7 \%$ influenced by another variables which not explained in this research models.

Keywords: investment decisions, financing decisions, dividend policy, the firm Value 


\section{PENDAHULUAN}

\section{Latar Belakang}

Dalam era industrialisasi yang semakin kompetitif sekarang ini, seorang manajer memegang peran penting atas kesuksesan perusahaan. Manajer perusahaan dituntut dapat mencapai tujuan perusahaan yaitu memakmurkan pemilik perusahaan atau para pemilik saham dengan memaksimalkan nilai perusahaan.

Menurut Sartono (2008:487), nilai perusahaan diartikan sebagai nilai jual sebuah perusahaan sebagai suatu bisnis yang sedang beroperasi. Nilai perusahaan sangat penting karena dengan nilai perusahaan yang tinggi akan diikuti oleh tingginya kemakmuran pemegang saham. Nilai perusahaan dapat tercermin dari harga saham, hal tersebut disebabkan karena harga saham di pasar modal terbentuk berdasarkan kesepakatan antara permintaan dan penawaran investor, sehingga harga saham merupakan fair price yang dapat dijadikan sebagai proksi nilai perusahaan (Hasnawati, 2005 dalam Wijaya, dkk. 2010). Oleh karena itu, setiap manajer perusahaan selalu berupaya meningkatkan harga sahamnya sebagai cerminan nilai perusahaan dalam memberikan sinyal kepada investor agar investor tertarik berinvestasi pada perusahaan tersebut.

Salah satu sarana investasi di pasar modal yang memberikan tingkat pengembalian yang tinggi dan kesejahtraan yang besar bagi investor yaitu indeks LQ 45. Indeks ini terdiri dari 45 saham dengan likuiditas (liquid) tinggi dan merupakan salah satu indikator indeks saham di BEI yang dapat dijadikan acuan sebagai bahan untuk menilai kinerja perdagangan saham. Hal ini dikarenakan saham LQ 45 memiliki kapitalisasi tinggi serta frekuensi perdagangan yang tinggi sehingga prospek pertumbuhan dan kondisi keuangan sahamnya baik. Sehingga dari kriteria tersebut, perusahaan-perusahaan yang tergolong di indeks LQ 45 merupakan perusahaan yang memiliki nilai perusahaan yang tinggi, hal tersebut terbukti dari rasio price to book value yang tinggi. Rasio PBV ini merupakan rasio yang sering digunakan untuk menilai atau mengukur nilai perusahaan (Ahmed dan Nanda, 2000). Menurut Ang (1997:18.44), price to book value merupakan rasio pasar yang digunakan untuk mengukur kinerja harga pasar saham terhadap nilai bukunya. Berdasarkan konsep price to book value harga saham dapat diketahui berada di atas atau di bawah nilai bukunya. Jika harga saham berada dibawah nilai bukunya, investor memandang bahwa perusahaan tidak cukup potensial, ini artinya investor pesimis atas prospek suatu saham yang menyebabkan banyak saham yang dijual dibawah nilai bukunya. Sebaliknya, jika investor optimis maka saham dijual dengan harga diatas nilai bukunya.

Berikut disajikan tabel nilai rata-rata harga saham dan nilai buku masing-masing perusahaan LQ 45 yang dijadikan sampel dalam penilitian ini adalah sebagai berikut :

Tabel 1. Rata-Rata Harga Saham (Closing Price) dan Nilai Buku Perusahaan LQ 45 yang terdaftar di BEI priode 2011-2015

\begin{tabular}{|c|c|c|c|c|c|c|c|c|c|c|c|}
\hline \multirow{2}{*}{ NO } & \multirow{2}{*}{ NAMA PERUSAHAAN } & \multicolumn{5}{|c|}{ HARGA SAHAM (Rp) } & \multicolumn{5}{|c|}{ NILAI BUKU (Rp) } \\
\hline & & 2011 & 2012 & 2013 & 2014 & 2015 & 2011 & 2012 & 2013 & 2014 & 2015 \\
\hline 1 & Astra Agro Lestari, Tbk & 21.700 & 19.700 & 25.100 & 24.250 & 15.850 & 5.351 & 5.947 & 6.520 & 7.517 & 7.429 \\
\hline 2 & Bank Central Asia, Tbk & 8.000 & 9.100 & 9.600 & 13.125 & 13.300 & 1.722 & 2.126 & 2.621 & 3.192 & 3.672 \\
\hline 3 & $\begin{array}{l}\text { Bank Negara Indonesia } \\
\text { (Persero), Tbk }\end{array}$ & 3.800 & 3.700 & 3.950 & 6.100 & 4.990 & 2.050 & 2.358 & 2.583 & 3.305 & 4.249 \\
\hline 4 & $\begin{array}{c}\text { Bank Mandiri (Persero), } \\
\text { Tbk }\end{array}$ & 6.750 & 8.100 & 7.850 & 10.775 & 9.250 & 2.712 & 3.313 & 3.844 & 4.539 & 5.173 \\
\hline
\end{tabular}




\begin{tabular}{|c|c|c|c|c|c|c|c|c|c|c|c|}
\hline \multirow{2}{*}{ NO } & \multirow{2}{*}{ NAMA PERUSAHAAN } & \multicolumn{5}{|c|}{ HARGA SAHAM (Rp) } & \multicolumn{5}{|c|}{ NILAI BUKU (Rp) } \\
\hline & & 2011 & 2012 & 2013 & 2014 & 2015 & 2011 & 2012 & 2013 & 2014 & 2015 \\
\hline 5 & $\begin{array}{c}\text { Charoen Pokphand } \\
\text { Indonesia, Tbk }\end{array}$ & 2.150 & 3.650 & 3.375 & 3.780 & 2.600 & 377 & 499 & 607 & 667 & 766 \\
\hline 6 & Gudang Garam Tbk & 62.050 & 56.300 & 42.000 & 60.700 & 55.000 & 12.760 & 13.828 & 15.288 & 17.270 & 19.754 \\
\hline 7 & $\begin{array}{c}\text { Indofood Sukses } \\
\text { Makmur Tbk }\end{array}$ & 4.600 & 5.850 & 6.600 & 6.750 & 5.175 & 3.600 & 3.888 & 4.370 & 4.695 & 4.911 \\
\hline 8 & $\begin{array}{c}\text { Indocement Tunggal } \\
\text { Prakasa Tbk }\end{array}$ & 17.050 & 22.450 & 20.000 & 25.000 & 22.325 & 4.274 & 5.275 & 6.242 & 6.733 & 6.483 \\
\hline 9 & $\begin{array}{c}\text { Jasa Marga (Persero) } \\
\text { Tbk } \\
\end{array}$ & 4.200 & 5.450 & 4.725 & 7.050 & 5.225 & 1.653 & 1.439 & 1.598 & 1.680 & 1.819 \\
\hline 10 & Lippo Karawaci Tbk & 660 & 1.000 & 910 & 1.020 & 1.035 & 408 & 497 & 614 & 765 & 820 \\
\hline 11 & $\begin{array}{l}\text { Pp London Sumatra } \\
\text { Indonesia Tbk }\end{array}$ & 2.250 & 2.300 & 1.930 & 1.890 & 1.320 & 856 & 920 & 969 & 1.058 & 1.075 \\
\hline 12 & $\begin{array}{c}\text { Tambang Batu Bara } \\
\text { Bukit Asam (Persero) } \\
\text { Tbk }\end{array}$ & 17.350 & 15.100 & 10.200 & 12.500 & 4.525 & 3.544 & 3.691 & 3.277 & 3.763 & 4.031 \\
\hline 13 & $\begin{array}{c}\text { Semen Gresik (Persero) } \\
\text { Tbk }\end{array}$ & 11.450 & 15.850 & 14.150 & 16.200 & 11.400 & 2.464 & 3.062 & 3.676 & 4.215 & 4.626 \\
\hline 14 & United Tractor Tbk & 26.350 & 19.700 & 19.000 & 17.350 & 16.950 & 7.373 & 8.659 & 9.557 & 10.342 & 10.522 \\
\hline & JUMLAH & 188.360 & 188.250 & 169.390 & 206.490 & 168.945 & 49.144 & 55.502 & 61.766 & 69.741 & 75.330 \\
\hline & RATA-RATA & 13.454 & 13.446 & 12.099 & 14.749 & 12.068 & 3.510 & 3.964 & 4.412 & 4.982 & 5.381 \\
\hline
\end{tabular}

Sumber : Data skunder yang diolah

Dari tabel 1. di atas, dapat diketahui bahwa rata-rata harga saham memperlihatkan harga nominal yang lebih tinggi dibandingkan nilai bukunya, dimana pada tahun 2011 ratarata harga saham sebesar 13.454 rupiah lebih besar dari nilai bukunya 3.520 rupiah, Pada tahun 2012 rata-rata harga saham sebesar 13.446 rupiah lebih besar dari nilai bukunya 3.964 rupiah, Rata-rata harga saham 2013 sebesar 12.099 rupiah lebih besar dari nilai bukunya 4.412 rupiah, tahun 2014 rata-rata harga saham sebesar 14.749 rupiah lebih besar dari nilai bukunya 4.982 rupiah dan pada tahun 2015 rata-rata harga saham sebesar 12.068 rupiah lebih besar dari nilai bukunya 5.381 rupiah. Hal ini membuktikan bahwa harga saham dihargai lebih tinggi dari nilai bukunya yang menyebabkan investor optimis akan prospek perusahaan di masa yang akan datang, sehingga menyebabkan nilai perusahaan meningkat.

Keputusan investasi menyangkut tindakan mengeluarkan dana saat sekarang sehingga diharapkan mendapatkan arus kas di masa yang akan datang dengan jumlah yang lebih besar dari dana yang dikeluarkan pada saat sekarang sehingga harapan perusahaan untuk selalu berkembang akan semakin terencana (Pudjiati dan Widanar, 2009). Tujuan dilakukannya keputusan investasi adalah mendapat laba yang besar dengan risiko yang dapat dikelola dengan harapan dapat mengoptimalkan nilai perusahaan (Afzal dan Abdul, 2012). Menurut Prasetyo (2011:109) jika perusahaan mampu menciptakan keputusan investasi yang tepat maka aset perusahaan akan menghasilkan kinerja yang optimal sehingga memberikan sinyal positif bagi investor yang nantinya akan meningkatkan harga saham dan menaikkan nilai perusahaan.

Keputusan investasi sangat dipengaruhi oleh ketersediaan dana perusahaan yang berasal dari sumber pendanaan internal (internal financing) dan sumber pendanaan eksternal (external financing). Seorang manajer harus mampu mengambil keputusan pendanaan dengan mempertimbangkan komposisi hutang dan modal sendiri yang akan digunakan oleh perusahaan. Dengan adanya komposisi yang optimal dari penggunaan hutang dan modal sendiri akan dapat mempengaruhi nilai perusahaan. Namun untuk mencapai komposisi yang optimal tersebut tidaklah mudah, manajer dihadapkan pada dua hal yaitu apabila manajer lebih mengandalkan sumber pembiayaan dari ekuitas perusahaan maka jumlah dividen yang tersalurkan kepada investor akan berkurang, 
selain itu perusahaan tidak mampu melakukan pengeluaran investasi yang besar karena kurangnya sumber dana. Selanjutnya apabila manajer terlalu mengandalkan pembiayaaan melalui hutang maka risiko bisnis yang akan ditanggung oleh perusahaan akan semakin besar karena adanya biaya bunga yang terlalu besar ditanggung oleh perusahaan.

Alternatif yang tepat adalah perusahaan harus mampu mengkombinasikan sumber pendanaan internal melalui ekuitas dan sumber pendanaan eksternal melalui hutang secara wajar dan seimbang, artinya perusahaan tetap mengandalkan pembiayaan internal melalui ekuitas dan sumber pendanaan eksternal melalui penggunaan hutang yang masih dalam tahap wajar atau masih dalam batas tertentu. Penggunaan hutang yang tepat akan mengakibatkan adanya penghematan pajak, hal ini sesuai dengan pernyataan Mogdiliani dan Miller yang menyatakan bahwa penggunaan hutang akan meningkatkan harga saham karena biaya bunga hutang adalah biaya yang mengurangi pembayaran pajak. Dengan adanya pengurangan pajak maka biaya modal perusahaan juga akan berkurang sehingga dapat meningkatkan harga saham yang nantinya akan berdampak pada peningkatan nilai perusahaan (Brigham dan Houston, 2011:184).

Selain keputusan investasi dan keputusan pendanaan, kebijakan dividen merupakan suatu masalah yang menjadi perhatian bagi para manajer dan ahli keuangan. kebijakan dividen adalah seberapa banyak pendapatan yang bisa dibayarkan sebagai dividen dan seberapa banyak dapat dipertahankan, karena terkadang pembagian dividen bagi sebagian investor bukanlah sinyal positif. Investor menganggap manajer perusahaan tidak peka pada peluang investasi yang akan mendatangkan keuntungan namun lebih memilih membagikan dividen. Sehingga, nilai perusahaan dapat turun karena kurangnya keinginan pemegang saham untuk menanamkan modalnya pada perusahaan tersebut (Gayatri dan Mustanda, 2012). Dilain sisi, pembagian dividen yang tinggi juga dapat memberikan sinyal positif, hal tersebut dikarenakan Penggunaan dividen sebagai isyarat berupa pengumuman yang menyatakan bahwa suatu perusahaan telah memutuskan untuk menaikkan dividen per lembar saham mungkin diartikan oleh penanam modal sebagai sinyal yang baik, karena dividen per saham yang lebih tinggi menunjukkan bahwa perusahaan yakin arus kas masa mendatang akan cukup besar untuk menanggung tingkat dividen yang tinggi (Weston dan Copeland, 1997:145). Oleh karena itu dari hal tersebut manajer harus mampu menentukan kebijakan dividen yang optimal, kebijakan dividen optimal adalah kebijakan dividen yang menghasilkan keseimbangan antara dividen saat ini, pertumbuhan dimasa depan, dan memaksimalkan harga saham perusahaan (Brigham dan Houston, 2011:211).

Penelitian sebelumnya masih terdapat perbedaan atara hasil peniliti satu dengan yang lainnya. Penelitian yang dilakukan oleh Rakmisyah dan Gunawan (2011). Gayatri dan Mustanda (2012), dan Verawati, dkk. (2016) menyatakan bahwa keputusan investasi memiliki pengaruh positif dan signifikan terhadap nilai perusahaan. Sedangkan penelitian yang dilakukan oleh Setiani (2013) dan Achmad dan Amanah (2014) menyatakan bahwa keputusan investasi memiliki pengaruh negatif dan tidak signifikan terhadap nilai perusahaan. Penelitian yang dilakukan oleh Gayatri dan Mustanda (2012), Herawati (2013), Setiani (2013) dan Ahmad dan Amanah (2014) menyatakan keputusan pendanaan berpengaruh positif dan signifikan terhadap nilai perusahaan, sedangkan penelitian Rakhimisyah dan Gunawan (2011), Herawati (2013), Ferina, dkk. (2015) dan Verawati, dkk. (2016) menyatakan bahwa keputusan pendanaan tidak berpengaruh terhadap nilai perusahaan. Penelitian yamg dilakukan oleh Wijaya, dkk. (2010) menyatakan kebijakan dividen berpengaruh positif dan siginifikan terhadap nilai perusahaan. Efni, dkk. (2011) menyatakan kebijakan dividen tidak berpengaruh 
terhadap nilai perusahaan sedangkan Rakhimisyah dan Gunawan (2011) menyakan kebijakan dividen memiliki pengaruh negatif dan signifikan terhadap nilai perusahaan.

Dari hasil penelitian tersebut, terdapat research gap sehingga peniliti tertarik meneliti kembali tentang "Pengaruh Keputusan Investasi, Keputusan Pendanaan dan Kebijakan Dividen terhadap Nilai Perusahaan".

\section{Rumusan Masalah}

1. Apakah keputusan investasi berpengaruh terhadap nilai perusahaan pada perusahaan LQ 45 tahun 2011-2015?

2. Apakah keputusan pendanaan berpengaruh terhadap nilai perusahaan pada perusahaan LQ 45 tahun 2011-2015?

3. Apakah kebijakan dividen berpengaruh terhadap nilai perusahaan pada perusahaan LQ 45 tahun 2011-2015?

4. Variabel manakah diantara keputusan investasi, keputusan pendanaan dan kebijakan dividen yang memiliki pengaruh paling dominan terhadap nilai perusahaan?

\section{TINJAUAN PUSTAKA}

\section{Tinjauan Teoritis}

\section{Teori Agensi}

Teori agensi menyatakan dalam perusahaan terdapat perbedaan kepentingan antara pemilik perusahaan yaitu investor dan manajer sebagai pengendali perusahaan. Pemisahan kepemilikan dan pengendalian dalam perusahaan modern mengakibatkan potensi konflik antara pemilik dan manajer. Tujuan utama perusahaan adalah memaksimalkan kemakmuran pemegang saham. Pihak manajemen diharapkan bertindak dan mengambil keputusan untuk kepentingan pemegang saham. Di dalam perusahaan besar atau yang go public, saham dapat dimiliki oleh banyak pemegang saham sehingga mereka bahkan tidak dapat mengungkapkan tujuan mereka, dan karenanya mereka hanya memiliki sedikit kendali atau pengaruh atas pihak manajemen.

Teori agensi (agency theory) berkaitan dengan nilai perusahaan karena adanya konflik antara agen (manajemen perusahaan) dan pemegang saham perusahaan yang dikenal principal. Agency theory mengasumsikan bahwa semua individu bertindak atas kepentingan mereka sendiri. Pemegang saham sebagai principal diasumsikan hanya tertarik pada hasil keuangan berupa pembagian dividen yang bertambah. Sedangkan manajer sebagai agent diasumsikan menerima kepuasan berupa kompensasi keuangan yang tinggi dan syarat-syarat yang menyertai dalam hubungan tersebut. Dengan demikian, maka perbedaan kepentingan antara pemegang saham dan manajer terletak pada maksimisasi manfaat (utility) pemegang saham (principal) dengan kendala manfaat (utility) dan insentif yang akan diterima manajer (agent). Adanya perbedaan kepentingan inilah yang memicu konflik antara pemilik (principal) dan manajer (agent) (Sudiyatno, 2010).

\section{Teori sinyal}

Isyarat atau signal merupakan suatu tindakan yang diambil perusahaan untuk memberi petunjuk bagi investor tentang bagaimana manajemen memandang prospek perusahaan (Brigham dan Houston, 2011:186). Sinyal ini berupa informasi mengenai apa yang sudah dilakukan oleh manajemen untuk merealisasikan 
keinginan pemilik. Informasi tersebut penting bagi investor dan pelaku bisnis karena informasi pada hakekatnya menyajikan keterangan, catatan atau gambaran, baik untuk keadaan masa lalu, saat ini maupun masa yang akan datang bagi kelangsungan hidup perusahaan dan bagaimana efeknya pada perusahaan.

Signalling theory menyatakan pengeluaran investasi memberikan sinyal positif tentang pertumbuhan perusahaan dimasa yang akan datang, sehingga meningkatkan harga saham sebagai indikator nilai perusahaan (Hasnawati, 2005 dalam wijaya, dkk. 2010). Peningkatan hutang dapat juga diartikan oleh pihak luar sebagai kemampuan perusahaan untuk membayar kewajiban di masa yang akan datang atau adanya risiko bisnis yang rendah, sehingga penambahan hutang dapat memberikan sinyal positif kepada investor.

Penggunaan dividen sebagai isyarat berupa pengumuman yang menyatakan bahwa suatu perusahaan telah memutuskan untuk menaikkan dividen per lembar saham mungkin diartikan oleh penanam modal sebagai sinyal yang baik, karena dividen per saham yang lebih tinggi menunjukkan bahwa perusahaan yakin arus kas masa mendatang akan cukup besar untuk menanggung tingkat dividen yang tinggi (Weston dan Copeland, 1997:145).

\section{Nilai Perusahaan}

Secara normatif tujuan dari pengelolaan keuangan perusahaan adalah untuk meningkatkan nilai perusahaan. Semakin tinggi nilai perusahaan maka kesejahtraan para pemegang saham akan semakin tinggi. Nilai perusahaan merupakan harga yang bersedia dibayar oleh calon pembeli apabila perusahaan itu dijual (Husnan dan Pudjiastuti, 2006:6). Dan bagi perusahaan yang menerbitkan saham di pasar modal, harga saham yang diperjualbelikan di bursa merupakan indikator nilai perusahaan.

Nilai perusahaan merupakan persepsi investor terhadap tingkat keberhasilan perusahaan yang sering dikaitkan dengan harga saham (Sujoko dan Soebiantoro, 2007). Oleh karena itu, setiap manajer berupaya untuk mempertahankan dan meningkatkan harga saham dalam upaya memberikan sinyal kepada investor bahwa prospek perusahaan bagus, akibatnya nilai perusahaan akan meningkat. Tujuan perusahaan itu dapat dicapai melalui pelaksanaan fungsi-fungsi manajemen keuangan dengan hati-hati dan tepat, salah satunya melalui keputusan investasi, pendanaan, dan kebijakan dividen. keputusan investasi, pendanaan, dan kebijakan dividen yang tepat dapat meningkatkan harga saham dan akhirnya nilai perusahaan meningkat.

Menurut Christiawan dan Tarigan (2007) terdapat beberapa konsep yang menjelaskan nilai perusahaan, yaitu nilai nominal, nilai instrinsik, nilai likuidasi, nilai buku dan nilai pasar. Nilai nominal adalah nilai yang tercantum secara formal dalam anggaran dasar perseroan. Nilai pasar adalah merupakan harga yang terjadi dari proses tawar-menawar di pasar saham. Nilai buku adalah nilai perusahaan yang dihitung dengan konsep dasar akuntansi. Nilai likuidasi adalah nilai jual seluruh aset perusahaan setelah dikurangi semua kewajiban yang harus dipenuhi. Konsep yang paling representatif untuk menentukan nilai suatu perusahaan adalah konsep instrinsik. Nilai perusahaan dalam konsep instrinsik bukan sekedar harga dari sekumpulan nilai aset, melainkan nilai perusahaan sebagai entitas bisnis yang memiliki kemampuan menghasilkan keuntungan dikemudian hari.

\section{Keputusan Investasi}

Menurut Pujiati dan Widanar (2009) keputusan investasi merupakan keputusan yang dikeluarkan perusahaan terkait dengan kegiatan perusahaan untuk melepaskan dana pada saat sekarang dengan harapan untuk menghasilkan arus dana 
masa mendatang dengan jumlah yang lebih besar dari yang dilepaskan pada saat investasi awal, sehingga harapan perusahaan untuk selalu tumbuh dan berkembang akan semakin jelas dan terencana. Tendelilin (2001:3) mengemukakan bahwa investasi adalah komitmen atas sejumlah dana atau sumber daya lainnya yang dilakukan saat ini, dengan haparan memproleh keuntungan di masa yang akan datang. Prasetyo (2011:109) menyatakan jika perusahaan mampu menciptakan keputusan investasi yang tepat maka aset perusahaan akan menghasilkan kinerja yang optimal sehingga memberikan sinyal positif bagi investor yang nantinya akan meningkatkan harga saham dan menaikkan nilai perusahaan. Hal ini sesuai dengan signaling theory yang menyatakan pengeluaran investasi memberikan sinyal positif tentang pertumbuhan perusahaan di masa datang, sehingga meningkatkan harga saham yang merupakan cerminan nilai perusahaan.

Menurut Haruman (2008), investasi adalah total asset perusahaan dari tahun ke tahun yang menunjukkan perkembangan investasi perusahaan. Pertumbuhan total asset dapat meningkatkan nilai perusahaan. Pertumbuhan asset ini akan memberikan sinyal positif kepada investor karena hal tersebut menunjukkan adanya investasi yang tinggi yang dilakukan oleh perusahaan sehingga hal tersebut dapat meyakinkan investor akan prospek prusahaan di masa yang akan datang.

\section{Keputusan Pendanaan}

Menurut Husnan dan Pudjiastuti (2006:251) menyatakan bahwa Keputusan pendanaan menyangkut tentang bentuk komposisi pendanaan yang akan dipergunakan oleh perusahaan. Sedangkan menurut Efni, dkk. (2011) menyatakan bahwa keputusan pendanaan menyangkut tentang keputusan perusahan mencari dana untuk membiayai investasi dan menentukan komposisi sumber pendanaan. Keputusan pendanaan merupakan satu kebijakan yang sangat penting bagi perusahaan, karena menyangkut perolehan sumber dana untuk kegiatan operasi perusahaan. Keputusan ini akan berpengaruh terhadap struktur modal perusahaan. Struktur modal merupakan komposisi antara hutang perusahaan dan modal sendiri perusahaan, perusahaan harus menentukan struktur modal yang optimal dalam keputusan pendanaannya. Struktur modal optimal ini menyangkut seberapa besar pengunaan hutang dan modal sendiri yang akan digunakan oleh perusahaan, setiap perusahaan memiliki sasaran struktur modal yang berbeda-beda. Jika perusahaan menetapkan keputusan untuk menggunakan sumber dana dari hutang, berarti leverage keuangan perusahaan meningkat, dan perusahaan akan menanggung biaya tetap berupa bunga. Keptusan ini diharapkan agar terjadi perubahan laba per lembar saham (EPS) yang lebih besar daripada perubahan laba sebelum bunga dan pajak (EBIT), sehingga nilai perusahaan akan meningkat (Sudiyatno, 2010).

Tujuan manajemen memaksimalkan nilai pasar hutang dan nilai pasar modal sendiri, dengan demikian perusahaan mampu untuk memaksimalkan nilai perusahaannya. Kondisi ini akan dicapai jika perusahaan mampu mengoptimalkan struktur modalnya, yaitu keseimbangan yang optimal antara proporsi hutang dengan proporsi modal sendiri, karena proporsi ini akan menghasilkan biaya modal yang minimal. Namun hal ini akan sulit ditempuh perusahaan, karena belum ada teori yang menjelaskan tentang berapa seharusnya besarnya struktur modal yang optimal tersebut.

Dalam mengambil keputusan pendanaan manajer dapat berlandaskan diri pada beberapa teori keuangan yaitu teori pendekatan Modigliani dan Miller, teori trade off (teori pertukaran), dan packing order theory. 


\section{Kebijakan Dividen}

Salah satu tingkat pengembalian yang diproleh oleh pemegang saham adalah dividen. Dividen merupakan pembagian keuntungan yang diberikan perusahaan dan berasal dari keuntungan (laba) yang dihasilkan perusahaan. Dividen diberikan setelah mendapat persetujuan dari pemegang saham dalam RUPS. Jika perusahaan penerbit sahamnya mampu menghasilkan laba yang besar maka ada kemungkinan pemegang saham akan menikmati keuntungan dalam bentuk dividen yang besar.

Kebijakan dividen merupakan kebijakan yang penting bagi perusahaan. Kebijakan ini melibatkan dua pihak yang memiliki kepentingan yang berbeda yaitu pemegang saham dan menajemen itu sendiri. Menurut Husnan dan Pusjiastuti (2012:297) kebijakan dividen menyangkut tentang masalah penggunaan laba yang menjadi hak para pemegang saham yaitu pembagian laba dalam jumlah deviden yang dibayarkan tergantung dari kebijakan setiap perusahaan.

Kebijakan dividen mempunyai pengaruh yang kuat terhadap harga pasar dari saham yang beredar. Oleh karena itu, manajer dituntut untuk membagikan dividen sebagai realisasi dari harapan para investor dalam mengeluarkan uangnya untuk membeli saham tersebut. Pembayaran dividen yang lebih besar cenderung akan meningkatkan harga saham. Dengan meningkatnya harga saham maka akan meningkatkan nilai perusahaan. Akan tetapi, pembayaran dividen yang semakin besar akan mengurangi kemampuan perusahaan untuk investasi sehingga akan menurunkan pertumbuhan perusahaan, selanjutnya akan menurunkan harga saham dan nilai perusahaan. Hal ini disebut dengan trade off dimana manajer tidak mudah dalam menentukan pilihan antara membagikan laba sebagai dividen atau diinvestasikan kembali.

Adanya trade off tersebut menyebabkan manajer dituntut untuk dapat mengambil kebijakan dividen yang optimal. Kebijakan dividen optimal adalah kebijakan dividen yang menghasilkan keseimbangan antara dividen saat ini, pertumbuhan dimasa depan, dan memaksimalkan harga saham perusahaan (Brigham dan Houston, 2011:211).

Terdapat beberapa teori berkenaan dengan kebijakan dividen. Miller dan Modigliani dengan teorinya dividend policy irrelevance menunjukkan bahwa berdasarkan asumsi-asumsi tertentu termasuk di antaranya para investor yang rasional dan suatu pasar modal yang sempurna, nilai pasar dari suatu perusahaan adalah terlepas dari kebijakan dividennya (Mai, 2010). Muncul bird in hand theory sebagai suatu teori relevansi dividen dan menolak dividend irrelevance theory dari Miller dan Modigliani. Teori bird in hand menyatakan investor lebih menyukai pengembalian dalam bentuk dividen daripada dalam bentuk capital gain. Selanjutnya muncul teori tax preference yang menyatakan bahwa karena ada pajak investor lebih menyukai capital gain daripada dividen. Selanjutnya muncul teori clientele effect yang menyatakan para investor mungkin tertarik kepada tipe dari saham-saham yang sesuai dengan preferensi konsumsi atau savings mereka. Dan selanjutnya muncul teori information content of dividends or signaling hypothesis. Menurut argumentasi teori ini, dividends berisi informasi dan oleh karenanya dapat digunakan sebagai suatu alat pemberian isyarat untuk mempengaruhi harga saham. Suatu pengumuman dari kenaikkan dividen adalah membawa berita baik dan karenanya reaksi-reaksi harga saham adalah menguntungkan, dan sebaliknya. Semua teori tersebut dapat menjadi acuan bagian investor dalam mengambil keputusan. 


\section{Hipotesis}

1. Pengaruh keputusan investasi terhadap nilai perusahaan.

Keputusan investasi adalah keputusan penanaman modal berjangka waktu lama yang menyangkut harapan terhadap hasil keuntungan yang diproleh perusahaan dimasa yang akan datang. Menurut Prasetyo (2011:109) perusahaan yang mampu menciptakan keputusan investasi yang tepat maka aset perusahaan akan menghasilkan kinerja yang optimal sehingga memberikan sinyal positif bagi investor yang nantinya akan meningkatkan harga saham dan menaikkan nilai perusahaan. Hal ini sesuai dengan dengan teori sinyal yang menyatakan bahwa pengeluaran investasi memberikan sinyal positif tentang perubahan perusahaan di masa depan, sehingga dapat meningkat harga saham sebagai indikator nilai perusahaan.

H1 : Semakin tinggi pertumbuhan asset maka semakin tinggi nilai perusahaan.

\section{Pengaruh keputusan pendanaan terhadap nilai perusahaan}

Keputusan pendanaan perusahaan merupakan suatu keputusan tentang bentuk dan komposisi pendanaan yang akan dipergunakan oleh perusahaan (Achmad dan Amanah, 2014). Pengambilan keputusan pendanaan erat kaitannya dengan struktur modal, karena penentuan struktur modal perusahaan akan berpengaruh terhadap nilai perusahaan. Struktur modal menunjukkan perbandingan jumlah total hutang dengan modal sendiri. Perusahaan yang menggunakan hutang dalam operasinya akan mendapat penghematan pajak, karena pajak dihitung dari laba operasi setelah dikurangi bunga hutang, sehingga laba bersih yang menjadi hak pemegang saham akan menjadi lebih besar dibandingkan dengan perusahaan yang tidak menggunakan hutang (Meythi, 2012).

Adanya penghematan pajak ini menyebabkan nilai perusahaan meningkat. Namun yang harus diperhatikan oleh perusahaan adalah seberapa besar penggunaan hutang tersebut, perusahaan tidak akan mungkin mengunakan hutang $100 \%$ dalam struktur modalnya. Hal itu disebabkan karena semakin besar hutang berarti semakin besar pula resiko financial. resiko financial yaitu resiko yang timbul karena ketidakmampuan perusahaan membayar bunga dan angsuran pokok hutang. Dalam kondisi demikian semakin besar hutang maka nilai perusahaan akan menurun. Perusahaan harus mampu menentukan besarnya hutang, karena dengan adanya hutang sampai batas tertentu akan dapat meningkatkan nilai perusahaan. Akan tetapi bila jumlah hutang melewati dari batas tertentu justru akan menurunkan nilai perusahaan. Jadi penggunaan hutang yang tepat atau masih dalam batas tertentu dapat meningkatkan nilai perusahaan karena adanya penghematan pajak. Pernyataan ini didukung oleh teori Mogdiliani dan Miller yang mengatakan bahwa penggunaan hutang (leverage) akan meningkatkan harga saham karena biaya bunga hutang adalah biaya yang mengurangi pembayaran pajak. Dengan adanya pengurangan pajak maka biaya modal perusahaan juga akan berkurang sehingga dapat meningkatkan harga saham yang nantinya akan berdampak pada peningkatan nilai perusahaan (Brigham dan Houston, 2011:184).

Signalling theory menyatakan perusahaan yang meningkatkan hutang (Leverage) dapat dipandang sebagai perusahaan yang yakin dengan prospek perusahaan di masa yang akan datang sehingga dapat meningkatkan nilai perusahaan.

$\mathrm{H} 2$ : Semakin tinggi pendanaan hutang maka semakin tinggi nilai perusahaan. 


\section{Pengaruh kebijakan dividen terhadap nilai perusahaan}

Kebijakan dividen (dividend policy) merupakan keputusan seberapa besar laba yang diperoleh perusahaan pada akhir tahun akan dibagi kepada pemegang saham sebagai dividen kas atau disimpan dalam bentuk laba ditahan sebagai sumber pendanaan perusahaan (Brigham dan Houston, 2011:211). Menurut teori Information Content of Dividend, investor akan melihat kenaikan dividen sebagai sinyal positif atas prospek perusahaan di masa yang akan datang. Semakin tinggi nilai kesehatan suatu perusahaan akan memberikan keyakinan kepada pemegang saham untuk memperoleh pendapatan berupa dividen di masa yang akan datang. Perusahaan yang dapat memberikan dividen tinggi akan mendapatkan nilai kepercayaan yang tinggi dari para investor karena investor lebih menyukai kepastian mengenai return investasinya dan mengantisipasi risiko ketidakpastian tentang kebangkrutan perusahaan sehingga hal ini tentu dapat meningkatkan nilai perusahaan.

H3 : Semakin tinggi dividen yang dibayarkan maka semakin tinggi nilai perusahaan.

\section{Kerangka Konseptual}

Penelitian ini dimaksud untuk mengetahui pengaruh variabel keputusan investasi yang diproksikan dengan total asset growth (TAG), keputusan pendanaan yang diproksikan dengan debt to equity ratio (DER) dan kebijakan dividen yang diproksikan dengan dividend payout ratio (DPR) terhadap nilai perusahaan yang diproksikan dengan price to book value (PBV). Gambaran kerangka penelitian ini sebagai berikut:

Gambar 1. Kerangka Konseptual

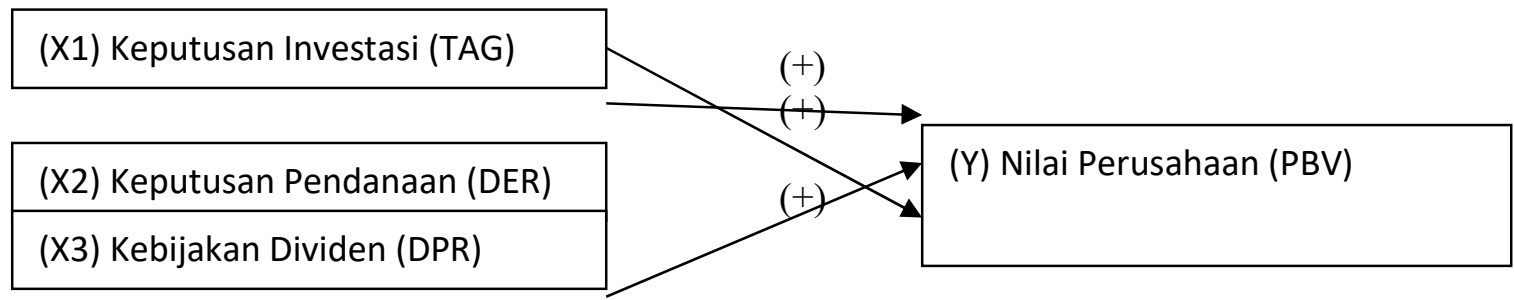

Keterangan :

$=$ Pengaruh

\section{METODELOGI PENELITIAN}

\section{Populasi dan Sampel}

Populasi merupakan wilayah generalisasi yang terdiri atas obyek/subyek yang mempunyai kualitas dan karekteristik tertentu yang ditetapkan oleh peneliti untuk dipelajari dan kemudian ditarik kesimpulannya (Sugiyono, 2009:72). Populasi penelitian ini adalah perusahaan yang tergolong dalam indeks LQ 45 di Bursa Efek Indonesia tahun 2011-2015.

Sampel merupakan bagian dari populasi yang digunakan sebagai objek penelitian, dalam penelitian ini sampel ditentukan dengan menggunakan metode purposive sampling. Metode sampling tersebut membatasi pemilihan sampel berdasarkan kriteria tertentu. Adapun kriteria perusahaan yang dijadikan sampel dalam penelitian ini adalah sebagai berikut : 
1. Perusahaan yang masuk dalam indeks LQ 45 di Bursa Efek Indonesia (BEI) berturut-turut selama periode 2011-2015.

2. Perusahaan yang mempublikasikan laporan keuangannya berturut-turut dari tahun 2011-2015.

3. Perusahaan yang konsisten membagi dividen kas selama periode 2011-2015

4. Perusahaan yang tidak melakukan stock split selama periode 2011-2015.

5. Perusahan yang mempublikasikan laporan keuangannya dalam bentuk satuan rupiah.

Penelitian ini menggunakan data time series dan cross section (pooling data), dan berdasarkan kriteria teknik sampling tersebut di atas, maka jumlah sampel yang memenuhi kriteria sebanyak 14 perusahaan. Jumlah tersebut diperoleh setelah dilakukan pemilihan sampel dengan mendasarkan pada kriteria teknik sampling yang telah ditentukan sebelumnya. Prosedur penentuan jumlah sampel yang akan digunakan dapat dilihat seperti pada tabel 2 berikut ini.

Tabel 2. Prosedur Pemilihan Sampel.

\begin{tabular}{|c|c|c|}
\hline Keterangan & $\begin{array}{c}\text { Tahun } \\
\text { 2011-2015 }\end{array}$ & Jumlah \\
\hline $\begin{array}{l}\text { Jumlah seluruh perusahaan yang } \\
\text { terdaftar di indeks LQ } 45\end{array}$ & 72 & 72 \\
\hline $\begin{array}{l}\text { Perusahaan yang keluar dari Indek LQ } \\
45\end{array}$ & (50) & 22 \\
\hline $\begin{array}{l}\text { Jumlah total Perusahan yang } \\
\text { konsisten berada di indeks LQ } 45\end{array}$ & 22 & 22 \\
\hline $\begin{array}{l}\text { Perusahaan yang tidak mencatum } \\
\text { Laporan Keuangannya }\end{array}$ & (1) & 21 \\
\hline $\begin{array}{l}\text { Perusahaan yang tidak membagikan } \\
\text { dividen kas }\end{array}$ & (0) & 21 \\
\hline Melakukan stock split & (4) & 17 \\
\hline $\begin{array}{l}\text { Perusahaan yang mempublikasikan } \\
\text { laporan kuangannya tidak dalam satuan } \\
\text { rupiah }\end{array}$ & (3) & 14 \\
\hline $\begin{array}{l}\text { Jumlah Perusahaan yang memenuhi } \\
\text { Kriteria }\end{array}$ & - & 14 \\
\hline
\end{tabular}

\section{Definisi Operasional Variabel}

Berdasarkan pokok masalah dan hipotesis yang diuji maka variabel yang digunakan dalam penelitian ini adalah :

\section{Variabel Dependen (Y)}

Nilai perusahaan dapat dilihat dari perbandingan antara harga pasar per lembar saham dengan nilai buku perlembar saham. Nilai perusahaan dalam penelitian ini adalah diproksikan dengan price to book value (PBV). Price to book value atau PBV menggambarkan seberapa besar pasar menghargai nilai buku saham suatu perusahaan. Semakin tinggi rasio ini berarti pasar percaya akan prospek perusahaan tersebut (Hermuningsih dan Wardani, 2009). PBV dapat dirumuskan sebagai berikut (Achmad dan Amanah, 2014) :

$$
P B V=\frac{\text { Harga per lembar saham }}{\text { Nilai buku per lembar saham }}
$$




\section{Variabel Independen $(\mathrm{X})$}

Dalam penelitian ini variabel independennya adalah sebagai berikut :

a. Keputusan Investasi

Keputusan investasi merupakan suatu keputusan untuk mengeluarkan dana pada saat sekarang untuk menghasilkan keuntungan di masa yang akan datang. Dalam penelitian ini Keputusan investasi diproksikan dengan total asset growth (TAG). Total asset growth merupakan rasio yang mengukur tingkat pertumbuhan total aset dari tahun ke tahun. TAG dapat dihitung dengan mengurangi asset tahun sekarang dengan asset tahun sebelumnya kemudian dibagi dengan asset tahun sebelumnya. Satuan ukurnya porsentase. TAG dapat dirumuskan sebagai berikut (Haruman, 2008) :

$$
(\mathrm{TAG})=\frac{\text { Total Asset }(t)-\text { Total Asset }(t-1)}{\text { Total Asset }(t-1)}
$$

b. Keputusan Pendanaan

Keputusan pendanaan adalah keputusan yang menyangkut komposisi pendanaaan antara hutang dan modal sendiri yang dipilih oleh perusahaan. Keputusan pendanaan dalam penelitian ini diproksikan dengan debt to equity ratio (DER). DER merupakan rasio yang membandingkan antara total hutang dengan total ekuitas atau modal sendiri. Satuan ukurnya adalah porsentase. DER dapat dirumuskan sebagai berikut (Husnan dan Pudjiastuti, 2096:74) :

\section{c. Kebijakan Dividen}

$$
\text { Debt to Equity Ratio }=\frac{\text { Total Hutang }}{\text { Total Ekuitas }}
$$

Kebijakan dividen adalah keputusan mengenai seberapa banyak laba saat ini yang akan dibayarkan sebagai deviden daripada ditahan untuk diinvestasikan kembali dalam perusahaan (Brigham dan Houston, 2011:211). Dalam penelitian ini kebijakan dividen diproksikan dengan dividend payout ratio (DPR). DPR merupakan perbandingan antara dividen per lembar saham dengan laba per lembar saham perusahaan (Gayatri dan Mustanda, 2012). Satuan ukurnya adalah porsentase. DPR dapat dirumuskan sebagai berikut (Wijaya, dkk. 2010) :

$$
\text { Dividend Payout Ratio }=\frac{\text { Dividen per Lembar Saham }}{\text { Laba per lembar Saham }}
$$




\section{HASIL DAN PEMBAHASAN PENELITIAN}

\section{Analisis Deskriptif Data}

Tabel 3. Analisis Deskriptif Data

\begin{tabular}{|l|r|r|r|r|r|}
\hline & $\mathrm{N}$ & Minimum & Maximum & \multicolumn{1}{|c|}{ Mean } & Std. Deviation \\
\hline Nilai Perusahaan (Y) & 70 & 1.0538 & 7.3146 & 2.991637 & 1.3545627 \\
Keputusan Investasi (X1) & 70 & -.0826 & .5636 & .167737 & .1050979 \\
Keputusan Pendanaan (X2) & 70 & .1536 & 8.0701 & 1.945341 & 2.5020475 \\
Kebijakan Dividen (X3) & 70 & .1240 & 1.2006 & .398784 & .2119316 \\
Valid N (listwise) & 70 & & & & \\
\hline
\end{tabular}

Sumber : Data Skunder yang diolah

Dari tabel 3 tersebut, dapat diketahui bahwa nilai maksimum untuk nilai perusahaan adalah 7,3146 atau $731,46 \%$ dan nilai minimumnya adalah 1,0538 atau $105,38 \%$ sedangkan nilai mean sebesar 2,9916 atau $299,16 \%$ dengan nilai standar deviasinya sebesar 1,3546 atau $135,46 \%$. Nilai maksimum untuk keputusan investasi sebesar 0,5636 atau $56,36 \%$, nilai minimum sebesar $-0,0826$ atau $-8,26 \%$, nilai mean sebesar 0,1677 atau $16,77 \%$ dan nilai standar deviasi sebesar 0,1051 atau $10,51 \%$. Keputusan pendanaan memiliki nilai minimum sebesar 0,1536 atau $15,36 \%$ dan nilai mamsimum sebesar 8,0701 atau 807,01\%, nilai mean sebesar 1,9453 atau 194,53\% dan standar deviasi sebesar 2,5020 atau 250,20\%. Kebijakan dividen memiliki nilai minimum sebesar 0,1240 atau $12,40 \%$ dan nilai maksimum sebesar 1,2006 atau $120,06 \%$, nilai mean sebesar 0,3988 atau $39,88 \%$ dan standar deviasi sebesar 0,2119 atau $21,19 \%$.

\section{Pengujian Asumsi Klasik}

Menurut Ghozali (2007) dalam pengujian asumsi klasik terdapat bebera pengujian yang harus dilakukan yaitu uji normalitas, uji multikolonieritas, uji autokorelasi, dan uji heteroskedastisitas. Berikut hasil uji normalitas:

Tabel 4. Hasil Uji Normalitas Data One-Sample Kolmogorov-Smirnov Test

\begin{tabular}{|ll|r|}
\hline & & Unstandardized Residual \\
\hline Normal Parameters & & 70 \\
& Mean & .0000000 \\
Most Extreme Differences & Std. Deviation & Absolute \\
& Positive & 1.21228460 \\
& Negative & .096 \\
Kolmogorov-Smirnov Z & & .088 \\
Asymp. Sig. (2-tailed) & & -.096 \\
\end{tabular}

a.Test distribution is normal

Sumber : Data Skunder yang diolah

Berdasarkan hasil pada tabel 4 diatas, menunjukkan bahwa data terdistribusi normal. Hal ini ditunjukkan dengan nilai Kolmogorov-Smirnov adalah 0,801 dan nilai Asymp. Sig pada 0,543 yang lebih besar dari 0,05 . Hal ini berarti data residual 
terdistribusi secara normal, karena nilai signifikansinya lebih besar dari 0,05 . Hasil Uji multikolineritas sebagai berikut:

Tabel 5. Hasil Uji Multikolinieritas

\begin{tabular}{|ll|r|r|l|}
\hline \multirow{2}{*}{ Model } & \multicolumn{2}{|c|}{ Collinearity Statistics } & \multirow{2}{*}{ Keterangan } \\
\cline { 3 - 4 } & & Tolerance & \multicolumn{1}{c|}{ VIF } & \\
\hline 1 & (Constant) & & & \\
& Keputusan Investasi (TAG) & .792 & 1.263 & Tidak terjadi Multikolonieritas \\
& Keputusan Pendanaan (DER) & .741 & 1.349 & Tidak terjadi Multikolonieritas \\
& Kebijakan Dividen (DPR) & .647 & 1.545 & Tidak terjadi Multikolonieritas \\
\hline
\end{tabular}

Sumber : Data Skunder yang diolah

Dari tabel 5 tersebut menunjukkan model regresi bebas dari gejala korelasi antar variabel bebas (independen). Hasil pengujian terhadap nilai tolerance dan VIF mengasilkan nilai tolerance dan VIF untuk semua variabel independen yaitu nilai tolerance di atas 0.1 dan nilai VIF jauh di bawah angka 10, sehingga semua variabel independen terbebas dari persoalan multikolonieritas. Selanjutnya uji autokorelasi sebagi berikut:

Tabel 6. Hasil Uji Durbin-Watson

\begin{tabular}{|c|c|c|c|c|c|}
\hline \multicolumn{6}{|c|}{ Model Summary $^{\mathbf{b}}$} \\
\hline Model & $\mathrm{R}$ & R Square & Adjusted R Square & $\begin{array}{l}\text { Std. Error of the } \\
\text { Estimate }\end{array}$ & Durbin-Watson \\
\hline 1 & $.446^{\mathrm{a}}$ & .199 & .163 & 1.2395304 & 2.112 \\
\hline
\end{tabular}

a. Predictors: (Constant), Kebijakan Dividen, Keputusan Investsi, Keputusan Pendanaan

b. Dependent Variable: Nilai Perusahaan

\section{Sumber : Data skunder yang diolah}

Pengujian ada atau tidaknya gejala autokorelasi pada model regresi dilakukan dengan uji Durbin-Watson. Nilai dL, dU, 4-dU, dan 4-dL sampel data sebesar 70 dengan $\alpha=0,05$ adalah 1,52 (dL), 1,70 (dU), 2,30 (4-dU), dan 2,48 (4-dL). Jadi, jika nilai Durbin-Watson terletak diantara dU s/d 4-dU atau 1,70 s/d 2,30 model regresi terbebas dari gejala autokorelasi.

Hasil pengujian autokorelasi dengan Durbin-Watson Test seperti yang tersaji pada Tabel 6 menunjukkan bahwa nilai DW-test sebesar 2,112. Sehingga dapat disimpulkan bahwa nilai DW terletak diantara dU s/d 4-dU atau lebih besar dari 1,70 dan lebih kecil dari 2,30 dan model regresi terbebas dari persoalan autokorelasi. Terakhir adalah uji heterokedastisitas sebagai berikut:

Tabel 7. Hasil Uji Park

\begin{tabular}{|c|c|c|c|c|c|c|}
\hline & & \multicolumn{2}{|c|}{ Unstandardized Coefficients } & \multirow{2}{*}{$\begin{array}{c}\text { Standardized } \\
\text { Coefficients }\end{array}$} & \multirow[b]{2}{*}{$\mathrm{t}$} & \multirow[b]{2}{*}{ Sig. } \\
\hline \multicolumn{2}{|c|}{ Model } & $\mathrm{B}$ & Std. Error & & & \\
\hline \multirow[t]{4}{*}{1} & (Constant) & -1.785 & .933 & & -1.913 & .060 \\
\hline & Keputusan Investasi (X1) & 3.980 & 2.396 & .225 & 1.661 & .101 \\
\hline & Keputusan Pendanaan (X2) & .068 & .104 & .092 & .656 & .514 \\
\hline & Kebijakan Dividen (X3) & 1.151 & 1.315 & .131 & .876 & .384 \\
\hline \multicolumn{3}{|c|}{$\begin{array}{l}\text { a. Dependent Variable: LNU2i } \\
\text { Sumber : Data skunder yang diolah }\end{array}$} & & & & \\
\hline
\end{tabular}

42 | Pengaruh Keputusan Investasi, Keputusan Pendanaan..... 
Hasil pengujian heteroskedastisitas seperti yang tersaji pada tabel 7 menunjukkan bahwa semua variabel independen yang dimasukkan dalam model regresi secara statistik tidak signifikan (sig- $\mathrm{t}=>0,05$ ) berpengaruh terhadap residual, maka model regresi terbebas dari persoalan heteroskedastisitas. Hasil pengujian heteroskedastisitas pada tabel 7 menunjukkan bahwa keputusan investasi yang diproksikan dengan TAG mempunyai nilai $\mathrm{t}=1,661$ dan nilai sig $=0,101$. Keputusan pendanaan yang diproksikan dengan DER mempunyai nilai t sebesar 0,656 dan nilai sig sebesar 0,514 sedangkan kebijakan dividen yang diproksikan dengan DPR mempunyai nilai t sebesar 0,876 dan nilai sig sebesar 0,384 . Jadi, semua variabel independen secara statistik tidak ada yang signifikan terhadap residual $\left(L n U^{2} i\right)$ atau mempunyai nilai sig-t lebih besar dari 0,05, sehingga dapat disimpulkan bahwa semua variabel independen yang dimasukkan dalam model regresi terbebas dari persoalan heteroskedastisitas.

\section{Uji F (Goodness of Fit)}

Tabel 8. Hasil UJi F

\begin{tabular}{|ll|r|r|r|r|r|}
\hline Model & & Sum of Squares & Df & Mean Square & F & \multicolumn{1}{c|}{ Sig. } \\
\hline 1 & Regression & 25.199 & 3 & 8.400 & 5.467 & $.002^{a}$ \\
& Residual & 101.405 & 66 & 1.536 & & \\
& Total & 126.604 & 69 & & & \\
\hline
\end{tabular}

Hasil pengujian menunjukkan bahwa nilai nilai $\mathrm{F}$ sebesar 5,467 dengan sig. $=$ 0,002 . Hal ini menunjukkan model regresi yang digunakan memenuhi kesesuaian model (goodness of fit) pada level signifikansi kurang dari 5 persen $($ sig. $=0,002)$.

\section{Uji t}

Tabel 9. Hasil Analisis Regresi Linier Berganda

\begin{tabular}{|c|c|c|c|c|c|c|}
\hline & & \multicolumn{2}{|c|}{$\begin{array}{l}\text { Unstandardized } \\
\text { Coefficients }\end{array}$} & \multirow{2}{*}{\begin{tabular}{c|}
$\begin{array}{c}\text { Standardized } \\
\text { Coefficients }\end{array}$ \\
Beta \\
\end{tabular}} & \multirow[b]{2}{*}{$\mathrm{t}$} & \multirow[b]{2}{*}{ Sig. } \\
\hline \multicolumn{2}{|c|}{ Model } & $\mathrm{B}$ & Std. Error & & & \\
\hline \multirow[t]{4}{*}{1} & (Constant) & 2.068 & .621 & & 3.329 & .001 \\
\hline & Keputusan Investasi & 5.608 & 1.595 & .435 & 3.515 & .001 \\
\hline & Keputusan Pendanaan & -.052 & .069 & -.096 & -.748 & .457 \\
\hline & Kebijakan Dividen & .209 & .875 & .033 & .239 & .812 \\
\hline \multicolumn{3}{|c|}{ a. Dependent Variable: Nilai Perusahaan } & & & & \\
\hline
\end{tabular}

\section{Sumber : Data Skunder yang diolah}

\section{Hipotesis 1}

Hasil penelitian diproleh koefesien regresi untuk variabel keputusan investasi sebesar 5,608 dan tingkat signifikansinya sebesar 0,001. Hal ini menunjukkan bahwa tingkat signifikansi berada dibawah 0,05 atau 5\%. Dengan demikian hipotesis pertama yang menyatakan bahwa keputusan investasi berpengaruh positif dan signifikan terhadap nilai perusahaan pada perusahaan LQ 45 atau semakin tinggi pertumbuhan asset maka semakin tinggi nilai perusahaan dapat diterima. 
Hasil penelitian ini dapat memberikan kontribusi bahwa keputusan investasi yang diproksikan dengan total asset growth (TAG) dapat digunakan untuk memprediksi dan menjelaskan nilai perusahaan. Hal ini disebabkan oleh tingkat siginfikansi dibawah 5\%. Hasil penelitian ini memberikan pemahaman empirik pada manajemen bahwa selama priode 2011-2015, pengeluaran investasi perusahaanperusahaan LQ 45 yang listed di BEI umumnya memiliki pengaruh besar terhadap nilai perusahaan, keputusan manajemen mengeluarkan biaya modal sebagai upaya ekspansi direspon positif oleh pelaku bursa. Respon positif ini mungkin diakibatkan oleh pengeluaran investasi yang dilakukan oleh perusahaan LQ 45 yang dapat memberikan NPV positif, sehingga keputusan investasi tersebut dapat menghasilkan tingkat return yang lebih tinggi daripada biaya modal yang dikeluarkan oleh perusahaan.

Karakteristik perusahaan LQ 45 sebagai perusahaan yang liquid memudahkan mereka untuk menggunakan modalnya dalam berinvestasi pada berbagai tempat. Tujuannya adalah untuk meminimalisir risiko dan memaksimalkan return akibat investasi yang dilakukan oleh perusahaan, sesuai dengan teori investasi "don't put all your eggs in one basket".

Disversifikasi investasi merupakan keputusan investasi yang tepat sebagai upaya meningkatkan laba perusahaan, seiring dengan kondisi perekonomian Indonesia yang masih stabil daripada negara-negara lain, sehingga hal ini memberikan dampak positif bagi perusahaan. Tercatat perokonomian Indonesia tahun 2011 sebesar 6,44\%, pada tahun 2012 sebesar 6,19\%, pada tahun 2013 sebesar 5,56\%, pada tahun 2014 sebesar 5,02\% dan pada tahun 2015 4,79\% (www.bps.go.id). Walaupun terlihat bahwa kondisi perekenomian Indonesia mengalami penurunan tetapi keadaan tersebut masih dalam keadaan stabil jika dibandingkan dengan negara lain, akibatnya permintaan daya beli masyarakat pun masih meningkat sehingga memicu perusahaan untuk terus melakukan ekspansi usaha guna menggenjot produksi untuk memenuhi permintaan masyarakat. Tingkat ekspansi besar inilah yang memikat investor untuk menanamkan modalnya pada saham-saham perusahaan LQ 45 yang pada akhirnya harga saham mengalami peningkatan dan nilai perusahaan pun meningkat.

Implikasi manajerial dari hasil pengujian hipotesis ini adalah bahwa pengeluaran biaya modal atau investasi dapat dirasakan pengaruhnya dalam jangka pendek maupun jangka panjang. Dalam jangka pendek, keputusan investasi yang dilakukan perusahaan mampu memberikan kontribusi yang besar terhadap kegiatan operasional sehingga dapat menghasilkan laba yang tinggi, sedangkan untuk jangka panjang pengeluaran investasi pada asset-asset dimana ditandai dengan asset yang dimiliki perusahaan semakin bertambah, sehingga hal tersebut mengidikasikan bahwa prospek perumbuhan perusahaan semakin tumbuh dan tentunya tingkat keuntungan yang didapatkan oleh pemilik modal di masa yang akan datang semakin bertambah.

\section{Hipotesis 2}

Hasil penelitian diproleh koefesien regresi untuk variabel keputusan pendanaan sebesar $-0,052$ dan tingkat signifikansinya sebesar 0,457 . Hal ini menunjukkan bahwa tingkat signifikansi berada di atas 0,05 atau 5\%. Dengan demikian hipotesis kedua yang menyatakan bahwa keputusan pendanaan berpengaruh positif dan signifikan terhadap nilai perusahaan pada perusahaan LQ 45 atau semakin tinggi pendanaan hutang maka semakin tinggi nilai perusahaan ditolak. Teori MM dengan pajak menyatakan bahwa struktur modal mempengaruhi 
nilai perusahaan dengan mempertimbangkan pajak perusahaan maupun pajak personal. Dalam teori MM ini dikemukakan bahwa peningkatan hutang akan meningkatkan nilai perusahaan karena adanya penghematan pajak. Teori struktur modal dengan pajak mengatakan bahwa semakin besar hutang untuk membiayai operasi perusahaan makin meningkatkan nilai perusahaan. Apabila hutang semakin besar pihak calon investor mempunyai kesan yang baik terhadap kemampuan perusahaan dalam penggunaan hutang. Persepsi yang baik tersebut cendrung meningkatkan permintaan saham sehingga harga saham meningkat dan juga nilai perusahaan meningkat. Namun kelemahan teori ini adalah tidak mempertimbangkan biaya yang timbul akibat adanya hutang berupa biaya keagenan dan biaya kebangkrutan (Efni, dkk. 2011).

Hasil penelitian ini bertentangan dengan teori MM dengan pajak. Hasil penelitian menunjukkan bahwa penggunaan hutang terbukti dapat memunculkan potensi buruk bagi perusahaan. Hal tersebut disebabkan karena penggunaan hutang sudah melewati batas optimal yang menyebabkan bunga dari hutang tidak dapat menjadi manfaat namun dapat menjadi biaya kebangkrutan. Sehingga hasil penelitian ini menguatkan penyataan teori trade off yang dikemukakan oleh Donaldson. Teori trade off menyatakan penggunaan hutang yang besar sampai batas tertentu akan meningkatkan nilai perusahaan. Jika melewati batas tersebut penggunaan hutang akan menurunkan nilai perusahaan manfaat hutang (penghematan pajak) lebih kecil dari biaya yang timbul akibat berhutang berupa biaya keagenan dan biaya kebangkrutan.

Oleh sebab itu, langkah yang tepat bagi perusahaan adalah tidak meningkatkan hutang lagi, peningkatan hutang justru akan berdampak pada munculnya biaya hutang yang terlalu besar sehingga berdampak pada pada kondisi perusahaan dan tentunya akan menurunkan nilai perusahaan secara signifikan. Jika perusahaan membutuhkan dana sebaiknya perusahaan lebih mengedepankan pendanaan melalui ekuitas, hal tersebut dapat ditempuh dengan penerbitan saham baru, keputusan ini sangat tepat karena investor memandang bahwa mereka akan mendapatkan kesejahtraan yang besar jika berinvestasi pada perusahaan yang tergolong dalam indeks LQ 45, hal tersebut disebabkan karena mereka memandang bahwa perusahaan yang terdaftar di indeks LQ 45 mempunyai prospek yang cerah, dengan hal ini investor akan menanamkan modalnya ke perusahaan dan jumlah modal perusahaan akan bertambah untuk membiayai kegiatan operasionalnya. Jika perusahaan mampu memaksimalkan kegiatan operasionalnya maka laba yang didapatkan oleh perusahaan semakin meningkat sehingga secara otomatis hal ini dapat meningkatkan nilai perusahaan.

\section{Hipotesis 3}

Hasil penelitian diproleh koefesien regresi untuk variabel kebijakan dividen sebesar 0,209 dan tingkat signifikansinya sebesar 0,812. Hal ini menunjukkan bahwa tingkat signifikansi berada di atas 0,05 atau 5\%. Dengan demikian hipotesis ketiga yang menyatakan bahwa kebijakan dividen berpengaruh positif dan signifikan terhadap nilai perusahaan atau semakin tinggi dividen yang dibayarkan maka semakin tinggi nilai perusahaan pada perusahaan LQ 45 ditolak. Hasil ini tidak sesuai dengan bird in hand theory dan signaling theory.

Hasil ini membuktikan bahwa tinggi rendahnya dividen yang dibayarkan kepada pemagang saham, tidak berkaitan dengan tinggi rendahnya nilai perusahaan. Kebijakan dividen merupakan hak pemegang saham untuk mendapatkan sebagian dari keuntungan perusahaan. Selain itu, investor dan pemegang saham tidak selalu 
menginginkan pembayaran dividen tinggi saat ini, ketika perusahaan yang sedang berkembang pesat dan tumbuh, maka para pemegang saham cendrung menginginkan keuntungan yang didapatkan oleh perusahaan diinvestasi kembali dalam hal pembuatan produk baru (inovasi produk), perluasan dan peningkatan penjualan, pembaharuan teknologi dan penambahan aset baru, sehingga hal tersebut dapat menciptakan tingkat profitabilitas atau keuntungan yang lebih besar dari keuntungan saat ini, sehingga dapat menarik investor untuk membeli saham perusahaan. Jika banyak investor yang membeli saham perusahaan, maka permintaan saham perusahaan menjadi meningkat. Teori permintaan menyatakan semakin tinggi permintaan, semakin tinggi harganya. Jika harga saham meningkat maka nilai perusahaan juga meningkat. Karena peningkatan nilai perusahaan tercermin dari harga saham perusahaan tersebut. Peningkatan harga saham dapat memberikan capital gain yang besar bagi pemilik modal akibat selisih harga saham sekarang dan sebelumnya, tentu hal ini memberikan keuntungan yang besar bagi pemilik modal karena selain mendapat capital gain yang besar juga dikenakan tarif pajak yang rendah.

Hasil penelitian ini memberikan bukti empiris yang sesuai dengan teori irelevan yang dikemukan oleh Prefessor Merton Miller dan Franco Miller (MM). Investor dan pihak luar cenderung tidak tertarik untuk mengetahui seberapa besar dividen yang dibagikan, karena mereka berpedoman bahwa tidak ada kebijakan dividen yang optimal. Menurut teori ini kebijakan dividen perusahaan tidak berpengaruh terhadap nilai perusahaan maupun biaya modanya. Berdasarkan sekumpul asumsi yang ketat, teori MM berpendapat bahwa nilai perusahaan hanya ditentukan oleh kemampuan dasarnya untuk menghasilkan laba dan resiko bisnisnya. Dengan kata lain, nilai perusahaan tergantung hanya pada pendapatan yang dihasilkan oleh aktivanya, bukan dari bagaimana pendapatan tersebut dibagi sebagai dividen.

\section{Variabel Dominan}

Berdasarkan hasil pengujian, pengaruh dominan dapat dilihat pada nilai Standardized Coefficients. Dari hasil penelitian diproleh nilai Standardized Coefficients untuk masing-masing variabel yaitu keputusan investasi sebesar 0,435, keputusan pendanaan sebesar -0,096 dan kebijakan dividen sebesar 0,033, sehingga dapat disimpulkan bahwa keputusan investasi mempunyai pengaruh paling dominan terhadap nilai perusahaan. 


\section{KESIMPULAN DAN SARAN}

\section{Kesimpulan}

Kesimpulan dari hasil penelitian ini adalah keputusan investasi berpengaruh positif dan signifikan terhadap nilai perusahaan. Sedangkan keputusan pendanaan dan kebijakan dividen tidak berpengaruh terhadap nilai perusahaan. Hasil penelitian ini menunjukkan bahwa 16,3\% perubahan nilai perusahaan dipengaruhi oleh keputusan investasi, keputusan pendanaan, dan kebijakan dividen, sedangkan sisanya sebesar $84,7 \%$ dipengaruhi oleh variabel lain yang tidak dijelaskan dalam model penelitian ini.

\section{Saran}

\section{Saran bagi perusahaan}

a. Perusahaan disarankan untuk dapat meningkatkan kembali investasinya dimasa akan datang, karena dari kegiatan investasi tersebut perusahaan dapat memproleh keuntungan yang besar.

b. Peusahaan disarankan untuk lebih memperhatikan keputusan keuangan yang mencerminkan kondisi keuangan internal perusahaan agar pengambilan keputusan dapat dilakukan dengan tepat.

\section{Saran bagi peneliti selanjutnya}

a. Penelitian ini hanya menggunakan tiga variabel independen untuk memprediksi nilai perusahaan. Untuk itu, peneliti selanjutnya dapat menambahkan variabel baru berupa faktor eksternal perusahaan sebagai variabel bebas atau memperkaya model dengan memasukkan variabel moderating dan variabel intervening.

b. Penelitian ini hanya menggunakan satu rasio sebagai proksi masing-masing variabel independen maupun variabel dependen. Untuk itu, peneliti selanjutnya dapat menggunakan lebih dari satu rasio untuk memperluas bentuk model penelitian. 


\section{DAFTAR PUSTAKA}

Achmad, Safitri Lia dan Amanah, Lailatul. 2014. Pengaruh Keputusan Investasi, Keputusan Pendanaan, Kebijakan Dividend dan Kinerja keuangan terhadap Nilai Perusahaan. Jurnal ilmu dan Riset Akuntansi Volume 3 No 9 Hal 1-15.

Afzal, Arie dan Abdul Rohman. 2012. Pengaruh Keputusan Investasi, Keputusan Pendanaan, dan Kebijakan Dividen terhadap Nilai Perusahaan. Journal of Accounting, 1(2): h:9

Ahmed, Parvez dan Nanda, Sudhir. 2000. Style Investing : Incorporating Growth Characteristics in Value Stocks. Pennsylvania State University at Harrisburg, pp $1-27$.

Ang, Robert.1997. Buku Pintar Pasar Modal Indonesia. Media Staff Indonesia. Jakarta

Brigham, Eugene F dan Houston, Joel F. 2011. Dasar-dasar Manajemen Keuangan,diterjemahkan oleh Ali Akbar Yulianto. Buku Kedua Edisi Kesebelas..Salemba Empat. Jakarta

Christiawan, Y. J. dan J. Tarigan. 2007. Kepimilikan Manajerial, Kebijakan Hutang, Kinerja dan Nilai Perusahaan. Jurnal Akuntansi dan Keuangan Volume 1 Hal 18

Efni, Yulia, Hadiwidjojo, Djumilah, Salim, Ubud dan rahayu, Mintari. 2011. Keputusan Investasi, Keputusan Pendanaan dan Kebijakan Dividen: Pengaruhnya terhadap Nilai Perusahaan (Studi pada sektor Properti dan Real Estate di Bursa Efek Indonesia). Jurnal Aplikasi Manajemen 1 Volume 10 no 1 Hal 128-141.

Ferina, Ika Sastri, Tjandrakirana, Rina dan Ismail, Ilham. 2015. Pengaruh Kebijakan Dividen, Kebijakan Hutang, Dan Profitabilitas Terhadap Nilai Perusahaan (Studi Pada Perusahaan Pertambangan Yang Terdaftar Di Bei Periode 2009. 2013). Jurnal Akuntanika Volume 2 No 1 Hal 52-66.

Gayatri, NI luh Putu Rassri dan I ketut Mustanda. 2012. Pengaruh Struktur Modal, Kebijakan Dividen, dan Keputusan Investasi terhadap Nilai Perusahaan. Jurnal akuntansi.

Ghozali, Imam. 2007. Aplikasi Analisis Multivariate dengan Program SPSS. Badang Penerbit Universitas Diponogoro, Semarang.

Haruman, T. 2008. Pengaruh Struktur Kepemilikan terhadap keputusan keuangan dan Nilai Perusahaan. Simposium Nasional Akuntansi XI, Pontianak.

Herawati, Titin. 2013. Pengaruh Kebijakan Dividen, Kebijakan Hutang dan Profitabilitas terhadap Nilai Perusahaan. Jurnal Manajemen Volume 2 no 2 Hal 1-18 
Hermuningsih, Sri dan Wardani, Dwi Kusuma.2009. Faktor-faktor yang mempengaruhi Nilai Perusahaan pada perusahaan yang terdaftar di Bursa Efek Malaysia dan Bursa Efek Indonesia. Jurnal Siasat Bisnis Volume 13 No 2 Hal : 173-183

Husnan, Suad dan Pudjiastuti, Enny. 2006. Dasar-dasar Manajemen Keuangan. Edisi Kelima. UPP AMP YKPN. Yogyakarta.

, Enny. 2012. Dasar-dasar Manajemen Keuangan. Edisi Keenam. UPP AMP YKPN. Yogyakarta.

Mai, Muhammad Umar. 2010. Dampak Kebijakan Dividen terhadap Nilai Perusahaan dalam kajian prilaku Oportunistik Manajerial dan Struktur Corporat Governance. Disertasi. Universitas Diponogoro Semarang, Semarang

Meythi. 2012. Pengaruh Struktur Modal terhadap Nilai Perusahaan dengan petumbuhan perusahaan sebagai Variabel Moderating. Program pendidikan Profesi Akuntansi, Universitas Kristen Maranatha, Bandung.

Prasetyo, Aries Heru. 2011. Valuasi Perusahaan. PPM. Jakarta.

Pujiati, Diyah dan Widanar, Erman. 2009. Pengaruh Struktur Kepemilikan Terhadap Nilai Perusahaan Keputusan Keuangan Sebagai Variabel Intervening. Jurnal Ekonomi Bisnis \& Akuntansi Ventura Volume 12 no 1 Hal 71-86.

Rakhimsyah, Leli Amnah dan Gunawan, Barbara. 2011. Pengaruh Keputusan Investasi, Keputusan Pendanaan, Kebikajan Dividen dan Tingkat Suku Bunga terhadap Nilai Perusahaan. Jurnal Bisnis dan Akuntansi Volume 7 no 1 Hal 31 45

Sartono, Agus. 2008. Manajemen Keuangan Teori dan Aplikasi Edisi Empat. BPFE, Yogyakarta.

Setiani, Rury. 2013. Pengaruh Keputusan Investasi, Keputusan Pendanaan, dan tingkat Suku Bunga terhadap Nilai Perusahaan pada perusahaan otomotif yang terdaftar di Bursa Efek Indonesia. Jurnal Manajemen Volume 2 no 1 Hal 1-10

Sudiyatno, Bambang. 2010. Peran Kinerja Perusahaan dalam menentukan pengaruh Faktor Fundamental Makroekonomi, Risiko Sistematis, dan Kebijakan Perusahaan terhadap Nilai Perusahaan (Studi Empirik pada Manufaktur di Bursa Efek Indonesia). Disertasi. Universitas Diponogoro Semarang, Semarang.

Sugiyono, 2009, Metode Penelitian Bisnis, Alfabeta, Jakarta

Sujoko, dan U. Soebiantoro. 2007. Pengaruh Struktur Kepemilikan Saham, Leverage, Faktor Intern dan Faktor Ekstern terhadap Nilai Perusahaan. Jurnal Manajemen dan Kewirausahaan 9 (1): 41-48

Tandelilin, Eduardus. 2001. Analisis Investasi dan Manajemen Portofolio. Edisi Pertama. BPFE, Yogyakarta 
Verawati, Merina Citra Indah, Kurniawati, Irra. 2016. Analisis Pengembangan Corporate Value berdasarkan Keputusan Investasi dan Pendanaan, Struktur Kepemilikan serta Kebijakan Dividen pada Perusahaan Manufaktur yang Terdaftar di Bursa Efek Indonesia. Barka Akuntansi dan Keuangan Indonesia Volume 1 No 1 Hal 15-34.

Wijaya, Lihan Rini Puspo. Bandi, dan Wibawa, Anas. 2010. Pengaruh Keputusan Investasi, Keputusan Pendanaan, dan Kebijakan Dividen terhadap Nilai Perusahaan. Simposium Nasional Akuntansi XIII Purwekerto. Hal 1-21.

Weston, J. Fred dan Copeland, Thomas E. 1997. Manajemen Keuangan. Edisi revisi kesembilan jilid dua. BPFE-UGM Yogyakarta.

www.bps.go.id. Diakses tanggal 28 November 2016

www.idx.co.id. Diakses tanggal 7 September 2016

www.sahamok.com. Diakses tanggal 7 September 2016

$50 \mid$ Pengaruh Keputusan Investasi, Keputusan Pendanaan..... 